\title{
THE EFFECT OF THREE PHASE TECHNIQUE ON STUDENTS' READING COMPREHENSION
}

\author{
Eko Saputra Nurdiansa ${ }^{1}$
}

${ }^{1}$ Halu Oleo University, Indonesia.

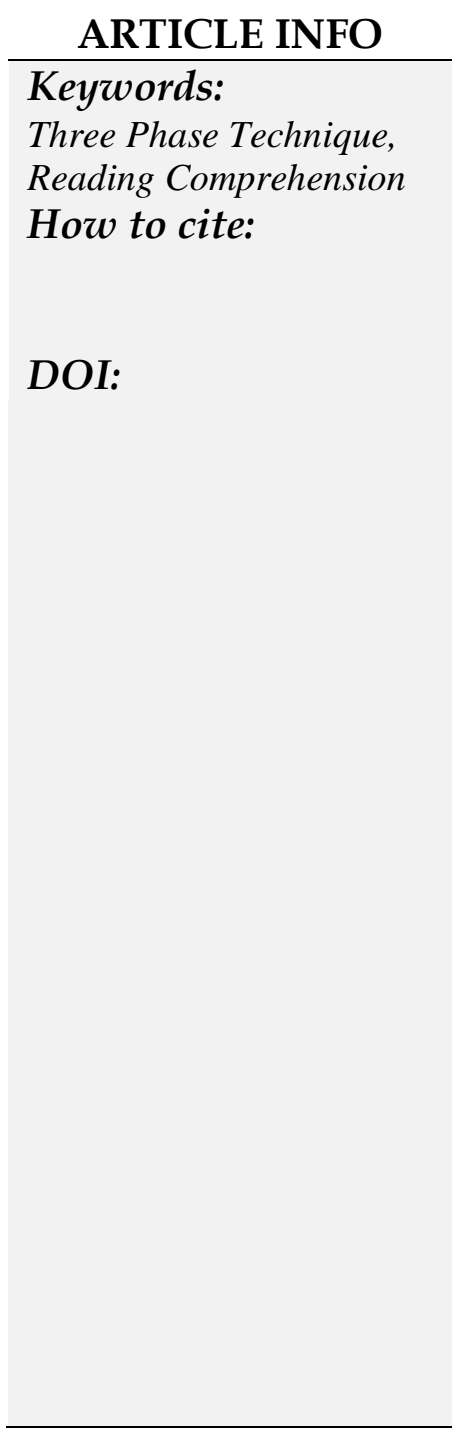

\begin{abstract}
The objective of the study is to know whether or not three phase technique has significant effect on students' reading comprehension. The design of this study was quasi experimental research. The population of the study were students who were taking Reading 1 class in English study program at Halu Oleo University in academic year of 2016-2017. By employing purposive sampling technique the researcher chose class $A$ as the sample of this study. Instrument of study was reading comprehension test in form of multiple choices questions. The result of this study confirmed that the teaching reading by using three phase reading technique could give significant effect on the students' reading comprehension. Based on the Paired Sample Test, it was found that there was a significant difference of students' reading comprehension score before and after they were given treatment by using three phase reading technique procedure in Reading 1 class with the significant degree of 0.013. Furthermore, there was also significant improvement in students' mean score (79.78). Therefore, the proposed hypothesis which stated "three phase reading technique has significant effect on students' reading comprehension" was accepted.
\end{abstract}

\section{Introduction}

The primary goal of teachers of English as a second language (ESL) or English as a foreign language (EFL) is to develop desired levels of English language communication skills among their nonnative English speaking students (Bernardo \& Gaerlan, 2011). This goal becomes very challenging for teachers because in order to 
achieve the learning objective they have to work hard to find teaching methods that suit the students' need. There are many aspects that need to be considered by teachers since learning English is an integrated process where students are demanded to master four basics skill namely listening, speaking, reading and writing (Ur, 1996).

From four basics skills above, reading is one of the significant competencies that need to be acquired well. Adequate ability of reading becomes one of the requirements which should be possessed by the students in order to get knowledge (Gersten et al, 2001). Reading is very important for students to get access into wider range information, expand and broaden their knowledge, insight and experience. Therefore, reading comprehension skill is significantly needed in acquiring those information and knowledge. Durkin (1993) stated that comprehension is the essence of reading and the active process of constructing meaning from text. This means that in reading process the reader interacts with the text content, using his or her vocabulary, background knowledge, skills, motivation to read the text, knowledge of the text structure, and strategies to construct meaning.

Bernhardt (1987) pointed out that comprehension is the process of relating new, or incoming information, to information stored in the memory. This indicates that reading comprehension is much related to one's prior knowledge or schemata. This implies that reading comprehension can be acquired better when students have the ability to explore and to connect the text they read with related prior information they have. Lack of the prior information will impede them from comprehending the text. Therefore, Khanam et al (2014) suggest that the teacher must take into account the knowledge on which any written text is based because if a reader is not actively using his/her background knowledge, a significant part of the reading process will not be taking place.

Background knowledge is essential in reading process. Therefore, language schema is a prerequisite for reading comprehension and teacher should be able to create the reading instruction that can activate students' prior knowledge. Carrell (1984) in Jahangard, et al (2012:100) defines activating schemata as a process enable students' background knowledge in comprehend the material. Similarly, Chia (2001) defines activating schemata as a teaching techniques that have been developed to activate student's prior knowledge.

Furthermore, activating students' prior knowledge in reading activity can be employed through three phase reading technique. Three Phase reading consists of a pre-reading preparatory stage, whilst reading stage and post reading stage (Mickulecky, 2004). First, pre-reading activities prepare and facilitate students to connect the new concept or topic more meaningfully to their prior knowledge. In theoretical terms such activities constitute attempts to activate the students' schemata; they may also provide language preparation, motivation, and variety in the classroom activity. Second, whilst reading phase involves exercises of guessing unknown word meaning, recovering pronoun reference, inference and prediction. It helps the students to understand the goals of the author, the structure of the text, and to explain the content of the text. Third, post reading phase is activity to 
consolidate and to reflect what the students have been read with their knowledge, interest, and their opinion.

The three phase of reading activity explained above is considered essential to lead students into good comprehension in reading. By employing this stages students can be more easily to build and connect their knowledge with the texts or reading materials provided by teacher. However, though three stage of reading activity is practically not a new teaching reading technique and has been applied by many, the researcher notices that it was still neglected and not optimally employed in teaching reading activity particularly in terms of pre-reading activity.

The researcher tends to give more concerns on pre-reading activity because pre-reading is an essential stage in reading activity to set up a purpose for reading as well as activating students' prior knowledge. This stage is important to prevent them from any failure in comprehending a piece of written text in the next stage of reading (whilst reading and post reading). It is supported by the result of some studies which showed that the well employed of pre-reading stage to activate students' prior knowledge (schemata) can significantly improve their reading comprehension (Khanam et al, 2014; Badri and Badri, 2014; Mardianti et al, 2014).

The researcher believes that devoting an optimal portion on the pre-reading activity and followed by well-organized whilst reading and post reading activities can give significant effect on students reading comprehension. Thus, the researcher conducted the study to investigate the effect of three phase technique on students' reading comprehension. In this study the researcher foregrounded pre-reading activity utilization without neglecting whilst reading and post reading activities.

Based on the background elaborated earlier, the researcher poses research question as follows: "Is there any significant effect of activating schemata on students' reading comprehension?"

\section{Methodology}

The design of this study was experimental research design. According to Sukardi (2003) there are three kinds of experimental research design namely preexperimental research, quasi esperimental research, and true esperimental reseach. From the three kinds of experimental research above the researcher used quasi experimental research as the design for this study. A quasi experimental research is an empirical study used to estimate the causal impact of an intervention on its target population (Dinardo, 2008). The design of this study used to describe the students' reading comprehension after being taught using Three Phase technique. This design also used pretest, treatment, and posttest.

\section{Pretest $\longrightarrow$ Treatment $\longrightarrow$ Posttest (Fraenkel and Wallen, 2000)}

The population of the study were Reading 1 class students of English Study Program at Halu Oleo University in academic year of 2016-2017. This study used purposive sampling technique to determine the sample. 
In this study the researcher used reading comprehension test in form of multiple choices questions as the instrument of this study. The test consisted of 35 items in multiple choice form which were be made by the researcher himself based on the reading materials. Before it is tested to the target classes, the researcher will administrate the pilot study procedure to examine the test validity and reliability. In the process of collecting the data, this study was conducted through 4 steps which were held systematically. These steps were pilot study, pre-test, treatment, and posttest.

After giving pre-test and post-test to the target class, the then researcher analyzed the students' scores by using scoring technique, data classical assumption analysis, and statistical data analysis.

The scoring technique in this study used scoring technique suggested by Sugiyono (2011). The formula can be seen as follows:

Total of correct answer

Mark = $x 10$

Maximum score

(Sugiyono, 2011)

The criteria of students' reading comprehension scores are as follows:

$$
\begin{array}{ll}
8-10 & =\text { Very high } \\
7-7,9 & =\text { High } \\
6-6,9 & =\text { Enough } \\
0-5,9 & =\text { Low }
\end{array}
$$

In this study the researcher analyzed the data distribution to find out the normality of the data by using one-sample Kolmogorov-Smirnov test. The principal of kolmogorov-smirnov test $(\mathrm{K}-\mathrm{S})$ is to calculate the deviation value between cumulative sample frequency distribution (Fs ( $x$ ) and theoretical cumulative sample frequency $(\mathrm{Ft}(\mathrm{x}))$. The formula of kolmogorov-smirnov is expressed as follows:

Where:

$$
D=\left|F_{s}(x)-F_{t}(x)\right| \max
$$

$\mathrm{D}=$ Deviation

$\mathrm{F}_{\mathrm{s}}(\mathrm{x})$ = cumulative sample frequency distribution

$\mathrm{F}_{\mathrm{t}}(\mathrm{x})=$ theoretical cumulative sample frequency

After conducting scoring procedure and data classical assumption the analysis, the researcher analyzed the data of pre-test and post-test by using inferential statistics analysis in order to examine the hypothesis of the study. The analysis procedures are described below:

a. To test the hypothesis, the researcher will use one tailed t-test. One tailed t-test can be defined as one direction test which can be used when the hypotheses 
proposed by the researcher has already been predicted to result positive effect (Sugiyono, 2007). It means that the hypothesis direction in this study can be predicted to result the positive effect. One-tailed t-test formula as follows:

$$
t=\frac{\bar{X}_{1}-\bar{X}_{2}}{\sqrt{\frac{S 1^{2}}{n_{1}}+\frac{S 2^{2}}{n_{2}}}}
$$

Where:

$\overline{X_{1}}=$ mean score of post-test

$\overline{X_{2}}=$ mean score of pre-test

$\mathrm{S}_{1}{ }^{2}=$ Variance score of post-test

$\mathrm{S}_{2}{ }^{2}=$ Variance score of pre-test

$\mathrm{n}_{1} \quad=$ Total sample of post-test

$\mathrm{n}_{2}=$ Total sample of pre-test, (Arikunto, 2003)

b. To examine whether the hypothesis was accepted or rejected the researcher used criteria as follows:

1. If $\mathrm{t}$-count $\geq \mathrm{t}$-table the hypothesis is accepted

2. If $\mathrm{t}$-count $\leq \mathrm{t}$-table the hypothesis is rejected

\section{Result and Data Analysis}

After calculating the normality of the data distribution of posttest on both experimental and control class, the researcher then analyzed whether or not there was significant difference of students' score of the experimental group and control group. In conducting this procedure the researcher applied independent sample $\mathrm{T}$ test by using statistics program of IBM SPSS Statistics version 23. The result was as follows:

Table 4.16

Independent Samples Test

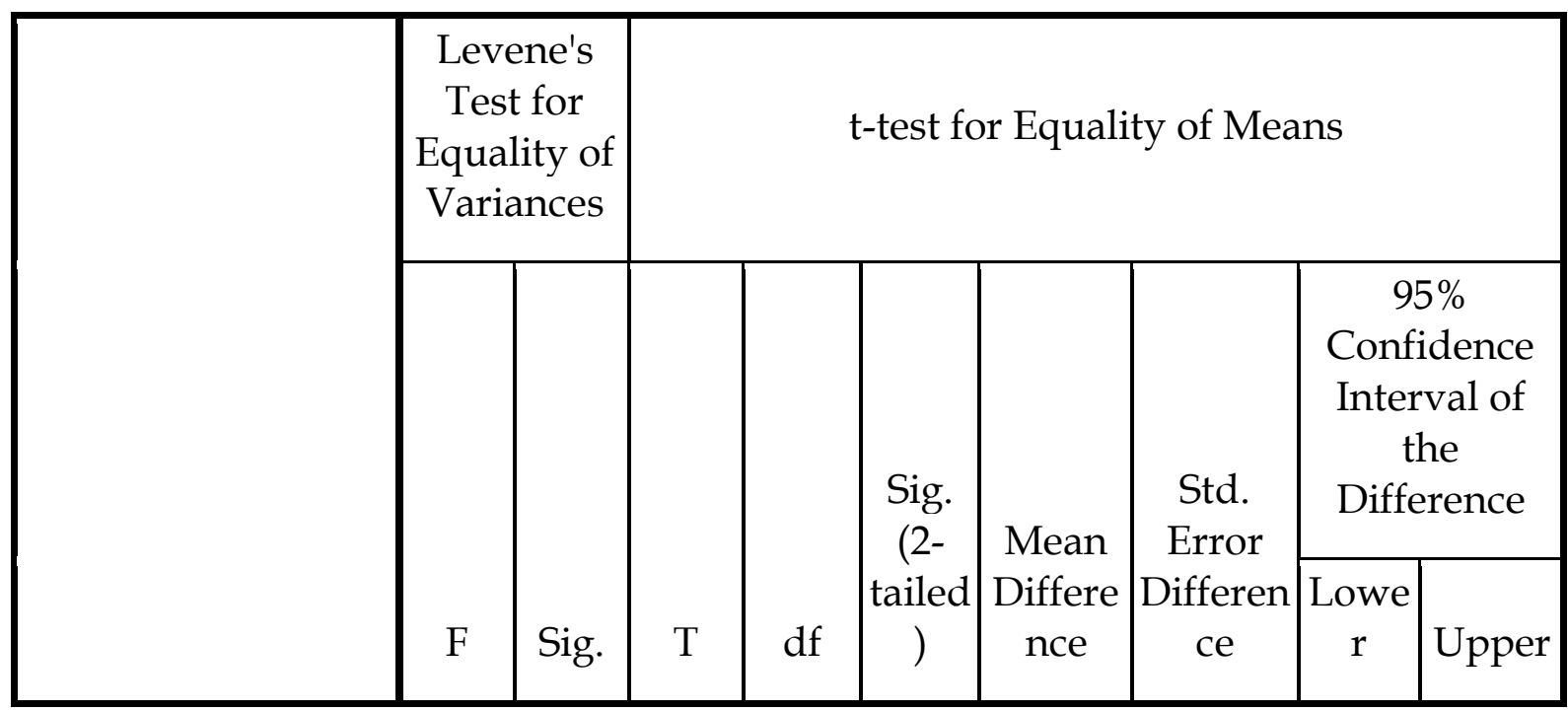




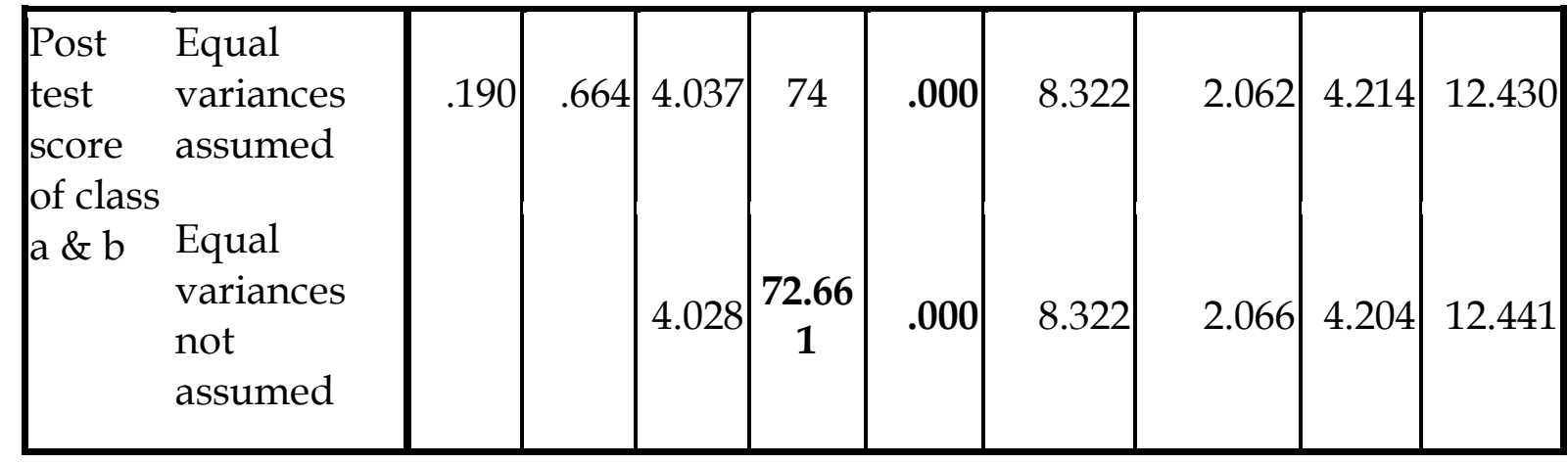

Sig. (2-tailed) $\leq 0.05$ = Significance difference

Sig. (2-tailed) $\geq 0.05=$ No significance difference

The table 4.16 showed that the numbers of subjects in this study for both the experimental and control groups was 76 with the degree of freedom $(\mathrm{df})=74(\mathrm{NX} 1+$ NX2 $-2=37+39-2=74$. The result of independent sample t-test for pre-test showed that $t$-value obtained was 4.037 and $t$ table for $\mathrm{df}$ (74) with significance degree 0.05 was 1.666 , so $t$-value was higher than t-table $(4.037>1.994)$. Furthermore, the independent sample t-test showed that sig. (2-tailed) was $0.000(\mathrm{p}<$ 0.05 ), and for the $95 \%$ Confidence Interval of the Difference was obtained 4.214 for the lower interval and 12.430 for the upper interval. The criteria to determine whether there was or no significant difference between control class and experimental class was by looking the $t$ value and Sign. (2-tailed) value. If the $t$ value was higher than $t$ table and sign. (2-tailed) value was lower than 0.05 then there was a significant difference between experimental class and control class. If the $t$ value was lower than $t$ table and sign. (2-tailed) value was higher than 0.05 then there was no the significant difference between experimental class and control class. Based on the data presented on the table 4.16 above, it could be concluded that there was a significant difference between experimental and control group in post-test.

\section{Comparison of Pre-Test and Post-Test in Control Class}

Comparing the students' pre-test and post-test score in the control class aimed at knowing the aggregate or the improvement of students reading comprehension after being taught by using conventional or usual instruction. The students' score difference between pre-test and post-test was described in table below:

Table 4.17

Comparison of Pre-Test and Post-Test Result in Control Class

\begin{tabular}{|c|c|c|c|}
\hline \multirow{2}{*}{$\begin{array}{c}\text { Descriptive } \\
\text { Analysis }\end{array}$} & \multicolumn{2}{|c|}{ Control Class } & $\begin{array}{c}\text { Gain Score } \\
\text { of Control } \\
\text { Class }\end{array}$ \\
\cline { 2 - 4 } & Pre-test & Posttets & \\
\hline Sum $\left(\sum\right)$ & 2641 & 2787 & 146 \\
\hline
\end{tabular}




\begin{tabular}{|c|c|c|c|}
\hline Mean Score & 67.71 & 71.46 & 3.75 \\
\hline SD & 8.73 & 8.61 & -0.12 \\
\hline Max Score & 80 & 87 & 7 \\
\hline Min Score & 47 & 57 & 10 \\
\hline
\end{tabular}

Table 4.17 showed that there was a difference on students' score in the control class in pre-test and posttest. The control class aggregate score (post-test-pre-test) was 146. It meant that the increasing of students' sum score in control class was 146. The mean score of control class also increased in 3.75 point. The maximum score of control class increased from 80.00 to 87.00 which gained aggregate point 7.00 . Based on the data in the table 4.17 above the researcher concluded that there was improvement of students' reading comprehension from pre-test to post-test. However, this improvement did not significant since the gained aggregate points was were small.

\section{Comparison of Pre-Test and Post-Test in Experimental Class}

After analyzing the students score of experimental class on pre-test and post-test as described on previous sub-chapter, the researcher described the comparison of students' pre-test and post-test in experimental class by using descriptive statistics. The purpose of comparing students' pre-test and post-test score in this section was to describe clearly the significant difference of students in experimental class before and after being taught by using activating schemata procedure. The comparison score can be seen in the table below:

Table 4.18

Comparison of Pre-Test and Post-Test Result in Experimental Class

\begin{tabular}{|c|c|c|c|}
\hline \multirow{2}{*}{$\begin{array}{c}\text { Descriptiv } \\
\text { e Analysis }\end{array}$} & \multicolumn{2}{|c|}{ Experimental Class } & $\begin{array}{c}\text { Gain Score of } \\
\text { Experimental Class }\end{array}$ \\
\cline { 2 - 4 } & Pre-Test & Post-Test & \\
\hline Sum ( $\left.\sum\right)$ & 2490 & 2952 & 462 \\
\hline $\begin{array}{c}\text { Mean } \\
\text { Score }\end{array}$ & 67.29 & 79.78 & 12.49 \\
\hline SD & 8.63 & 9.35 & 0.72 \\
\hline Max Score & 80 & 97 & 17 \\
\hline Min Score & 37 & 60 & 23 \\
\hline
\end{tabular}

Table 4.18 showed that there was a difference on students' score on pre-test and post-test in the experimental class. There was significant improvement of students' post-test score compared to pre-test score. The experimental class 
aggregate score (posttest-pretest) was 462. It meant that the increasing of students' sum score in experimental class after treatment procedure by using activating schemata was increase to 462 point. The mean score of experimental class also increased t0 12.49 point. The maximum score increased from 80.00 to 97.00 which gained aggregate point 17.00 .

In addition, the researcher also compared students' score in the experimental class to the students' score in the control class. It was really important to find out the aggregate or significant difference between students' score with treatment by using activating schemata procedures compare to conventional teaching procedure by using three phase reading strategy. Students' differences could be seen from the descriptive statistics analysis from both classes as in the following table.

Table 4.19

Descriptive Analysis of Students' Score on Pre-Test and Post-Test in Experimental Class and Control Class

\begin{tabular}{|l|c|c|c|c|c|c|}
\hline \multirow{2}{*}{$\begin{array}{c}\text { Descriptive } \\
\text { Analysis }\end{array}$} & Experimental Class & \multicolumn{2}{c|}{ Control Class } & \multicolumn{2}{c|}{ Gain Score } \\
\cline { 2 - 7 } & Pre-Test & Post-Test & Pre-Test & Post-Test & E. Class & C. Class \\
\hline Sum ( $\sum$ ) & 2490 & 2952 & 2641 & 2787 & 462 & 146 \\
\hline Mean Score & 67.29 & 79.78 & 67.71 & 71.46 & 12.49 & 3.75 \\
\hline SD & 8.63 & 9.35 & 8.73 & 8.61 & 0.72 & -0.12 \\
\hline Max Score & 80 & 97 & 80 & 87 & 17 & 7 \\
\hline Min Score & 37 & 60 & 47 & 57 & 23 & 10 \\
\hline
\end{tabular}

Table 4.19 showed that there was a difference score between score before and after using activating schemata procedures at Reading 1 Students in both the experimental class and the control class. It could be seen from the gain score of pretest and post-test of each class. The gained score (post-test score - pre-test score) or the aggregate of experimental class was 462 while the control class aggregate score was only 146. It indicated that the increasing of students' sum score in experimental class was higher than control class. The mean score of experimental class also increased in point of 12.49 compared to mean score in control group which only gained 3.75 point. The maximum score of experimental class increased on 17 point compare to control class which only gained 7 point.

Based on the comparison of gained score above, the researcher concluded that there was a significant difference of students' reading comprehension in the treatment class which was taught by using activating schemata procedures 
compared to the control class that was taught by using conventional procedure. The data on the table 4.19 above showed that there was a different level of students in control and experimental class after being given treatment. Therefore, the researcher concluded that the students who were taught by using activating schemata procedures got more significant result in reading than the students who were taught by using conventional technique. This indicated that using activating schemata procedure in teaching reading was more effective compared to the conventional teaching procedure.

\section{Hypothesis Testing}

This sub-chapter aimed to test the proposed hypothesis in this study. After analyzing the students score of experimental and control group on pre-test and posttest as described on previous sub-chapter, the researcher then tested the hypothesis proposed in this study. This hypothesis testing used Paired-Sample T-Test. According to SPSS Base User Guide (2007: 286), the Paired-Samples T-Test procedure compares the means of two variables for a single group where the procedure computes the differences between values of the two variables for each case and tests whether the average differs from 0. It meant that Paired-Sample T-Test aimed at computing two variables before and after treatment from single data source. In this study the researcher compared the mean value of two variables namely pre-test and post-test from one single group namely experimental class. This Paired-Sample TTest was the suitable and fitted analysis procedure to know the degree of improvement of students' score from pre-test to post-test. The result of PairedSample T-Test was as follows:

Table 4.20

Paired Samples Statistics

\begin{tabular}{|l|c|c|c|c|}
\hline & Mean & $\mathrm{N}$ & $\begin{array}{c}\text { Std. } \\
\text { Deviation }\end{array}$ & $\begin{array}{c}\text { Std. Error } \\
\text { Mean }\end{array}$ \\
\hline Pair 1 Class a pretest \\
$\begin{array}{l}\text { score } \\
\begin{array}{l}\text { Class a posttest } \\
\text { score }\end{array}\end{array}$ & 67.2973 & 37 & 8.63412 & 1.41944 \\
\hline
\end{tabular}

Table 4.21

Paired Samples Correlations

\begin{tabular}{|l|l|c|c|}
\hline & $\mathrm{N}$ & $\begin{array}{c}\text { Correlatio } \\
\mathrm{n}\end{array}$ & Sig. \\
\hline
\end{tabular}


Paired Samples Correlations

\begin{tabular}{|c|c|c|c|}
\hline & $\mathrm{N}$ & $\begin{array}{c}\text { Correlatio } \\
\mathrm{n}\end{array}$ & Sig. \\
\hline $\begin{array}{l}\text { Pair } 1 \text { class a pretest score } \\
\text { \& class a posttest } \\
\text { score }\end{array}$ & 37 & .805 & .013 \\
\hline
\end{tabular}

Table 4.22

Paired Samples Test

\begin{tabular}{|c|c|c|c|c|c|c|c|c|}
\hline & \multicolumn{5}{|c|}{ Paired Differences } & \multirow[b]{3}{*}{$\mathrm{t}$} & \multirow[b]{3}{*}{$\mathrm{df}$} & \multirow{3}{*}{$\begin{array}{l}\text { Sig. (2- } \\
\text { tailed) }\end{array}$} \\
\hline & \multirow[b]{2}{*}{ Mean } & \multirow{2}{*}{$\begin{array}{c}\text { Std. } \\
\text { Deviation }\end{array}$} & \multirow{2}{*}{$\begin{array}{l}\text { Std. } \\
\text { Error } \\
\text { Mean }\end{array}$} & \multicolumn{2}{|c|}{$\begin{array}{l}\text { 95\% Confidence } \\
\text { Interval of the } \\
\text { Difference }\end{array}$} & & & \\
\hline & & & & Lower & Upper & & & \\
\hline $\begin{aligned} \text { pair } 1 & \text { class a } \\
& \text { pretest } \\
& \text { score - } \\
& \text { class a } \\
\text { posttest } & \text { score }\end{aligned}$ & -1.24865 & 9.83368 & 1.61665 & -15.76520 & -9.2077 & 7.724 & 36 & .000 \\
\hline
\end{tabular}

To examine whether the hypothesis was accepted or rejected the researcher used criteria as follows:

a. If $\mathrm{t}$-count $\geq \mathrm{t}$-table the alternative hypothesis $\left(\mathrm{H}_{1}\right)$ was accepted and null hypothesis $\left(\mathrm{H}_{0}\right)$ was rejected, it meant that activating schemata has significant effect on students' reading comprehension.

b. If $\mathrm{t}$-count $\leq \mathrm{t}$-table the alternative hypothesis $\left(\mathrm{H}_{1}\right)$ was rejected and null hypothesis $\left(\mathrm{H}_{0}\right)$ was accepted, it meant that activating schemata does not have significant effect on students' reading comprehension.

Based on the output statistics above, the researcher explained the result as follows; the table 4.21 showed the correlation score between pre-test and posttest was 0.805 which indicated the strong and positive correlation. The significance degree was 0.013 which indicated the result was significant on the level 0,05 or $5 \%$. Table 4.22 showed df (degree of freedom) was 36 (n-1). Based on the T-table (see appendx 10) the value of df: 36 with significant degree 0.05 was 1.688 , this $t$-table value was compared to the t-statistics 7.724 as showed on the table 4.22. The comparison of $t$-statistics and $t$-table clearly showed that $t$-statistics or $t$-count was 
higher than $\mathrm{t}$-table $(7.724>1.688)$. It meant that the proposed hypothesis which stated "activating schemata has significant effect on students' reading comprehension" was accepted. In addition the Sig. (2-tailed) as the probability value/ $p$ value on the T Paired test was 0.00 which lower than $0.05(p<0.05)$ on the degree of confidence of $95 \%$. It indicated that there was a significant difference of students' reading comprehension score before and after students were given treatment by using activating schemata procedure in Reading 1 class.

\section{Discussion and Conclusion}

The objective of the research was to know whether or not activating schemata has significant effect on students' reading comprehension on class A of English Department students of Halu Oleo University in the academic year of 2016/2017. By comparing students' mean score on posttest between control and experiment class, the researcher found that the mean score of students who were taught by using activating schemata procedures was higher than the mean score of students who were taught by using conventional technique $(79.78>71.46)$. It meant that the students' who were taught by using activating schemata procedures got more significant improvement in reading comprehension than the students who were taught by using conventional technique. Thus, it could be stated that there was a significant difference of students' reading comprehension between both strategies.

The result of this research confirmed that the teaching reading by using activating schemata procedures could give significant effect on the students' reading comprehension. It was indicated by the result of statistical analysis in determining the differences of students reading comprehension in experimental and control class. The researcher found that the result of students reading in posttest for experimental class after being taught by using activating schemata procedures was higher than control class who were taught by conventional technique. In short, the hypothesis testing result showed that teaching reading by using activating schemata procedures gave significant effect to the students' reading comprehension.

Based on the above discussion, the application of activating schemata procedures had proved could give significant effect to students' reading comprehension. This result in line with Anderson (1984) who points out that every act of comprehension involves one's knowledge of the world as well. Schemata are accepted as interlocking mental structures representing readers' knowledge of ordinary events (Brown, 2001; Harmer, 2003; Nasaji, 2002). In the reading process, readers integrate the new information from the text into their preexisting schemata (Wallace, 2001). Not only do schemata influence how they recognize information but also how they store it.

Furthermore, the result if this study also support the previous studies conducted by different researcher in different setting. First, Khanam et al (2014) investigate the role of schema for effective EFL reading comprehension of of tertiary level students in Bangladesh. Their study results suggest the important role of activating schemata on students' reading comprehension. Second, Badri and Badri (2014) investigate the effects of activating background knowledge on Iranian EFL learners' reading comprehension. The results indicated a significant improvement in 
the reading scores of the subjects in the experimental group. In other words, the results displayed an increase in students' performance in reading comprehension due to the effect of activating schemata activities. Third, the study conducted by Mardianti, Ohoiwutun and Wahyudin (2014) to improve students' reading comprehension through schema activation strategy. The result of their study showed that the use of schema activation strategy can significantly improve the students' reading comprehension.

Based on the findings of this study, it could be seen that there was a significant effect of activating schemata procedures toward students' reading comprehension at the Reading 1 students of English Department Halu Oleo University. The students' score of reading who were taught by using activating schemata procedures was higher than those who were taught by using conventional technique. The comparison of $t$-statistics and $t$-table clearly showed that $t$-statistics or t-count was higher than t-table which indicated the significant improvement of students' score after being taught by using activating schemata procedures.

Furthermore, by comparing students' mean score on post test between control and experiment class, the researcher found that the mean score of students who were taught by using activating schemata procedures was higher than the mean score of students who are taught by conventional technique. It meant that the improvement of students' reading score who were taught by using activating schemata procedures was higher than the students who were taught by conventional technique. Thus, it can be stated that there is a significant difference of students' reading comprehension between both strategies.

In conclusion, the whole explanations above show that activating schemata procedures was more effective in increasing the students' reading comprehension rather than conventional technique which is employed by lecturer. In other words, the students got higher scores in experiment class than in control class.

\section{References}

Ajideh, P. (2003). Schema Theory-Based Pre-Reading Tasks: A Neglected

Essential In The ESL Reading Class. Iran: Tabriz University .

Alderson, J. C. (2000). Assessing reading. Cambridge language assessment series.

An, S. (2013). Schema theory in reading. Theory and Practice in Language

Studies, 3(1), 130.

Anderson, R. C. (1978). "Schema-directed processes in language comprehension "in Lesgold, A.et al(eds) cognitive psychology and instruction. New York: Plenum.

Anderson, Richard C., et al. "Frameworks for comprehending discourse." American educational research journal 14.4 (1977): 367-381.

Anderson, R. C. (1984). Role of the reader's schema in comprehension, learning, and memory. Learning to read in American schools: Basal readers and content texts, 29, 243-257. 
Arikunto, S. 2003. Dasar-Dasar Evaluasi Pendidikan. Jakarta: Bumi Aksara.

Badri, Ali., Badri, Golnaz. (2014). The Effects of Activating Background Knowledge on Iranian EFL Learners' Reading Comprehension (A Study in Payame Noor University, Tehran, Iran). International Journal of Language Learning and Applied Linguistics World. Vol. 7 (4) 224-231.

Bernardo, A. B., \& Gaerlan, M. J. M. (2011). Non-Native English Students Learning in English: Reviewing and Reflecting on the Research. Global perspectives, local initiatives: Reflections and practices in ELT, 1-9.

Bernhardt, E. B. (1987). Cognitive processes in L2: An examination of reading behaviors. Research on second language acquisition in classroom settings, 35-50.

Bilokcuoglu,H.(2011).The effect of pre-reading activities in EFL classes on Students' reading comprehension. LAU Sosyal Bilimler Dergisi,2(2),79.

Bransford, J. D., \& Johnson, M. K. (1972). Contextual prerequisites for understanding: Some investigations of comprehension and recall. Journal of verbal learning and verbal behavior, 11(6), 717-726.

Brown, H. D. (2001). Teaching by principles: an interactive approach pedagogy.

New York: Addison Wesley. Longman, Inc.

Calfee, R. C., \& Patrick, C. L. (1995). Teach your children well: bringing K-12 education into the 21st century. Stanford Alumni Assn.

Carrell, P. L., \& Eisterhold, J. C. (1983). Schema theory and ESL reading pedagogy. TESOL quarterly, 17(4), 553-573.

Chia, H.L. (2001). Reading activities for effective top-down Processing. FORUM, $39(1)$

Cohavi, A. (2013). How did Whatsapp became the strongest social network? Calcalist.

Cranny, F., Anne, F. \& Martin, JR. 1982. Making new meanings: literary and linguistic perspectives on the function of genre in textual practice. English in Australia 105.1993. 30-44.

Durkin, D. (1993). Teaching them to read. Allyn and Bacon.

Fraenkel, J. R., Wallen, N. E., \& Hyun, H. H. (1993). How to design and evaluate research in education (Vol. 7). New York: McGraw-Hill.

Gay, L. R., Mills, G. E., \& Airasian, P. W. (2011). Educational research: Competencies for analysis and applications. Pearson Higher Ed.

Gilakjani, A. P., \& Ahmadi, S. M. (2011). The Relationship between L2 Reading Comprehensionand Schema Theory: A Matter of Text Familiarity. International Journal of Information and Education Technology, 1(2), 142.

Gersten, R., Fuchs, L. S., Williams, J. P., \& Baker, S. (2001). Teaching reading comprehension strategies to students with learning disabilities: A review of research. Review of educational research, 71(2), 279-320.

Grabe, W. (1991). Current developments in second language reading 
research. TESOL quarterly, 25(3), 375-406.

Grabe, W. 2010. Fluency in reading. 22. 71-83. Retrieved from:http://nflrc.hawaii.edu/rfl. Retrieved February 2, 2017.

Harmer, J. (2003). The practice of English language teaching. London/New York.

Hornby, A. S. (1995). Oxford Advanced learner's dictionary. Oxford: Oxford University Press.

Hudson, T. (2007). Teaching second language reading. Oxford: Oxford University Press.

Iqbal, M., Noor, M., Muhabat, F., \& Kazemian, B. (2015). Factors Responsible for Poor English Reading Comprehension at Secondary Level.

Jahangard, A., Moinzadeh, A., \& Karimi, A. (2012). The Effect of Grammar vs. Vocabulary Pre-teaching on EFL Learners' Reading Comprehension: A Schema-Theoretic View of Reading. Journal of English language teaching and learning, 3(8), 91-113.

Just, M. A., \& Carpenter, P. A. (1980). A theory of reading: From eye fixations to comprehension. Psychological review, 87(4), 329.

Khanam, S., Zahid, S. H., \& Mondol, S. (2014). The Role of Schema for Effective EFL Reading Comprehension. ASA University Review, 8(1), 83-93.

Mardianti, V. (2014). Improving students' reading comprehension through schema activation strategy. Elts journal, 2(1).

Margono. 2004. Metodologi Penelitian Pendidikan. Jakarta: Rineka Cipta.

Mikulecky, B.S, and Jeffries, L. 2007. More Reading Power. Addison-Wesley Publishing Company. ISA.

Munby, J. (1981). Communicative syllabus design: A sociolinguistic model for designing the content of purpose-specific language programmes. Cambridge University Press.

Nassaji, H. (2002). Schema Theory and Knowledge-Based Processes in Second Language Reading Comprehension: A Need for Alternative Perspectives. Language learning, 52(2), 439-481.

National Reading Panel (US), National Institute of Child Health, \& Human Development (US). (2000). Report of the national reading panel: Teaching children to read: An evidence-based assessment of the scientific research literature on reading and its implications for reading instruction: Reports of the subgroups. National Institute of Child Health and Human Development, National Institutes of Health.

Nuttal, C. 2000. Teaching Reading Skills in a Foreign Language. Oxford: Practical Language Teaching Series.

Ogata, H., Akamatsu, R., \& Yano, Y. (2005). Computer supported ubiquitous learning environment for vocabulary learning using RFID tags. Technology enhanced learning, 121-130.

Pang, E. S., Muaka, A., Bernhardt, E. B., \& Kamil, M. L. (2003). Teaching reading (Vol. 12). Brussels,, Belgium: International Academy of Education. 
Qanwal, S., \& Karim, S. (2014). Identifying correlation between reading strategies instruction and L2 text comprehension. Journal of Language Teaching and Research, 5(5), 1019-1033.

Rahman, M. H. (2007). An evaluation of the teaching of reading skills of English in Bangladesh. Master in English.

Rauch, S. J. \& Weinstein, A. B. (1968). Mastering Reading Skills. New York: D. Van Nostrand Company.

Reinders, H., \& Lewis, M. (2009). Podquests: Language games on the go. Language games: Innovative activities for teaching English, ed. M. Andrade, 76-85.

Shang, H. F. (2010). Reading strategy use, self-efficacy and EFL reading comprehension. Asian EFL Journal, 12(2), 18-42.

Sharples, M., Taylor, J., \& Vavoula, G. (2010). A theory of learning for the mobile age. In Medienbildung in neuen Kulturräumen (pp. 87-99). VS Verlag für Sozialwissenschaften.

Shuttleworth, M. 2014. Hawthorne effect-observation bias. [ online ] explorable.com. Avaible at: https:/ / explorable.com/hawthorne-effect.

Sugiyono. (2007). Metode penelitian pendidikan. Bandung : Alfabeta.

Suryabrata. (2008). Psikologi Pendidikan. Jakarta: Grapindo Persada.

Susanti, A., \& Tarmuji, A. (2016). High school students'reflection toward free applications for efl self-learning. SIEC 2016.

Swales, J. M. (1990). Discourse analysis in professional contexts. Annual review of applied linguistics, 11, 103-114.

Tan, A., \& Nicholson, T. (1997). Flashcards revisited: Training poor readers to read words faster improves their comprehension of text. Journal of Educational Psychology, 89(2), 276.

Troike, M. S. (2006). Introducing second language acquisition. Cambridge University Press.

Ur, P. (1996). A course in language teaching: practice and theory. London: Cambridge University Press.

Urquhart, A. H., \& Weir, C. J. (2014). Reading in a second language: Process, product and practice. Routledge.

Vacca, R. T., \& Vacca, J. A. L. (2002). Content area reading. Glenview, IL: Scott, Foresman.

Vygotsky, L. (1978). Interaction between learning and development. Readings on the development of children, 23(3), 34-41.

Wallace, M. (2001). Tropics of Globalization: Reading the New North America. symploke, 9(1), 145-160.

Yu-hui, L., Li-rong, Z., \& Yue, N. (2010). Application of Schema Theory in Teaching College English Reading. Canadian Social Science, 6(1), 59.

Zare, P., \& Othman, M. (2013). The relationship between reading comprehension and reading strategy use among Malaysian ESL learners. International Journal of Humanities and Social Science, 3(13), 187-193.

Zhang, L. J. (2010). A dynamic metacognitive systems account of Chinese university students' knowledge about EFL reading. Tesol Quarterly, 44(2), 320-353. 